
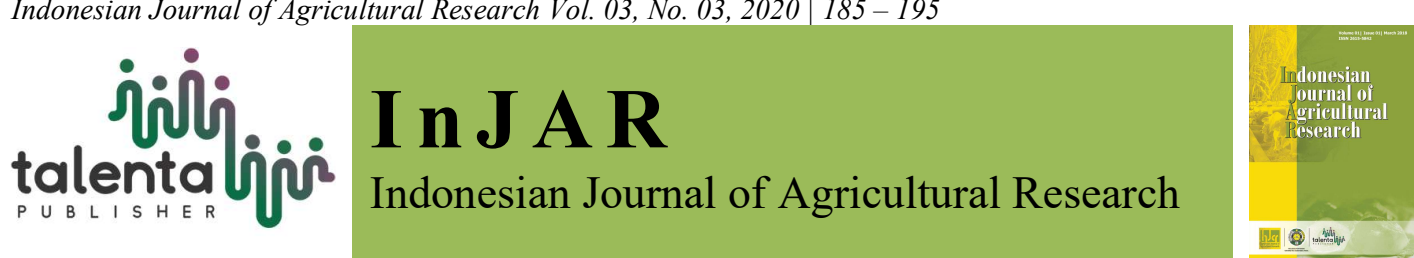

\title{
Development Model on Prevention of Land and Forest Fire in the Peat Land Area with Empowerment Society Approach (Case Study in West Kalimantan)
}

\author{
Maswadi *, Shenny Oktoriana, Rini Hazriani, and Maulidi
}

University of Tanjungpura, Pontianak, Indonesia

\begin{abstract}
Land fires are an annual agenda in Indonesia, especially in areas covered by peatlands. Peatland management using fire is the main cause. The general paradigm for land fires is that the farmers' economy is low. In fact, the factors that cause land fires are not only from the economic aspect, but from the social and institutional aspects which affect the behavior of farmers. Therefore, the purpose of this study is (1) to analyze the correlation of factors that influence land burning behavior, and (2) to determine the model for the changing of burning behavior into non burning farm land cultivation, in order to prevent land fire in Kuburaya Disrict and Bengkayang District, West Kalimantan. The research involved farmers farming on peatlands in both districts. Regression models was used for the correlation analysis. Based on the results of the regression analysis, a land burning behavior change model was determined based on the influencing factors descriptively. The result of the analysis showed the factors that significantly influence land burning behavior at the household level are knowledge level (consist of farming problems faced by farmers, agricultural extension materials and the application of technology), observance of rules, activeness of mutual assistance, cosmopolitan level, appraisal on burning behavior, and imitation level. The resulting model for changing the behavior of burning land is implementing activity of assistance, social capital stimulus and positive agreements/pressure to the land users.
\end{abstract}

Keywords: changing behavior, land burning behavior, peatland fires

Received 22 August 2020 | Revised 3 October 2020 | 2 January 2021

\section{Introduction}

The issue of forest and land fires is an annual agenda in Indonesia that occurs during the dry season. The negative impacts of forest and land fires can be felt in terms of health and the environment. In addition, these negative impacts are not only felt by the Indonesian people, but also globally, namely contributing to the increase in greenhouse gas emissions that cause global warming.

\footnotetext{
Corresponding author at: University of Tanjungpura, Bansir Laut, Pontianak Tenggara, Pontianak, West

Kalimantan, Indonesia

E-mail address: maswadi@faperta.untan.ac.id
} 
The occurrence of forest and land fires is caused by human behavior in using fire in peatland areas, where it is known that during the dry season peatlands are very susceptible to fire if there is a source of fire which then spreads uncontrollably. The use of fire by humans in locations prone to land fires is generally carried out deliberately, whether in the farming land processing stage, when hunting, cleaning the environment or originating from cigarette butts. The problem is that the fire source can cause land and forest fires due to human negligence because it does not protect the fire source until it is completely extinguished so that the fire spreads to a wider area and eventually gets out of control.

Based on these conditions, it is known that the occurrence of land and forest fires is closely related to the activities of the community around the locations prone to land fires. Therefore, it is necessary to analyze the factors that influence the behavior of fire use in the land, so that a model for forest and land fire prevention can be formulated that can be applied in the community.

Analysis of the behavior of fire use in its activities on farmland is the objective of the Socioeconomic survey, which is part of the Community Development Program for Prevention of Land Fires in Peat Areas which was carried out in the 2010-2015 period. The program is implemented in collaboration between the Ministry of Forestry and the Japan International Cooperation Agency (JICA), as well as the Tanjungpura University Faculty of Agriculture Team as the executor of survey and research activities. The main objective of the program is the prevention of land and forest fires in peat areas in Indonesia through a community empowerment approach.

\section{Research Methods}

\subsection{Research Location and Sample}

Survey activities were carried out in Bengkayang and Kubu Raya Regencies, West Kalimantan Province for five years (2011-2016). The fifth-year socio-economic survey was conducted in 23 villages, consisting of 10 villages in Bengkayang Regency and 13 villages in Kubu Raya Regency for West Kalimantan Province with a total of 1560 households as respondents. The research sample is farmer households that cultivate land, either land with ownership or lease / hold or labor status.

\subsection{Data Analysis}

The analysis carried out to predict the factors that influence farmers' behavior in using fire on the land has continued to develop during the survey period, namely improvements in the approach and measurement of variables and the structure of the model used, among others. The model that best predicts the behavior of burning land is produced through several stages of model trials, namely: 
a. District level regression analysis, namely analyzing the factors that influence the behavior of burning land using survey data in Bengkayang and Kubu Raya Regencies separately;

b. Provincial level regression analysis, namely analyzing the behavior of burning land by combining survey data in Bengkayang and Kubu Raya Districts for West Kalimantan Province;

The results of the analysis show that the model that best describes the behavior of burning land is to use a model that uses provincial level data, namely a separate analysis of data from both districts. The prediction of the factors that influence the burning behavior can be seen from three aspects, namely the probability of land burning behavior, the frequency of burning land and the area of land burned, which are arranged into three models:

$$
\begin{aligned}
& Y_{1}=\alpha+\beta_{1} x_{1}+\beta_{2} x_{2}+\beta_{3} x_{3}+\beta_{4} x_{4}+\beta_{5} x_{5}+\beta_{6} x_{6}+\beta_{7} x_{7}+\beta_{8} x_{8}+\beta_{9} x_{9}+\beta_{10} x_{10}+ \\
& \beta_{11} x_{11}+\beta_{12} x_{12}+\beta_{13} x_{13}+\beta_{14} x_{14}+\beta_{15} x_{15}+\beta_{16} x_{16}+\beta_{17} x_{17}+\beta_{18} x_{18}+\beta_{19} x_{19}+ \\
& \varepsilon \\
& Y_{2}=\alpha+\beta_{1} x_{1}+\beta_{2} x_{2}+\beta_{3} x_{3}+\beta_{6} x_{6}+\beta_{7} x_{7}+\beta_{8} x_{8}+\beta_{10} x_{10}+\beta_{11} x_{11}+\beta_{12} x_{12}+ \\
& \quad \beta_{13} x_{13}+\beta_{14} x_{14}+\beta_{15} x_{15}+\beta_{16} x_{16}+\beta_{17} x_{17}+\beta_{18} x_{18}+\beta_{19} x_{19}+\varepsilon \\
& Y_{3}=\alpha+\beta_{1} x_{1}+\beta_{2} x_{2}+\beta_{3} x_{3}+\beta_{6} x_{6}+\beta_{7} x_{7}+\beta_{8} x_{8}+\beta_{10} x_{10}+\beta_{11} x_{11}+\beta_{12} x_{12}+ \\
& \beta_{13} x_{13}+\beta_{14} x_{14}+\beta_{15} x_{15}+\beta_{16} x_{16}+\beta_{17} x_{17}+\beta_{18} x_{18}+\beta_{19} x_{19}+\varepsilon
\end{aligned}
$$

Where:

$\begin{array}{lll}Y_{1} & = & \text { Behavior probability of burning land }(1=\text { burning, } 0=\text { not burning) } \\ Y_{2} & =\text { Frequency of burning land (times in } 5 \text { years) } \\ Y_{3} & =\text { Area burned }\left(\mathrm{m}^{2}\right) \\ x_{1} & =\text { Diffusion rate of innovation (total score) }\end{array}$

Measuring the ability of respondents to accept and apply new innovations in farm management. The total score is the total score of the indicators:

1. Ability to solve problems (very capable $=3$; capable $=2$; unable to $=$ 1)

2. Frequency of participation in counseling (high frequency $(>2$ times $)=$ 3 ; medium frequency $(1-2$ times $)=2$; low frequency $(<1$ time $)=1)$

The determination of frequency is based on tendency central from the overall respondents' answers

3. The number of materials received in counseling (height ( $>3$ material) $=3$; medium $(1-3$ material $)=2$; low $(<1$ material $)=1)$

The determination of the amount of material is based on tendency central from the overall respondents' answers. Extension materials consist of (a) seed quality improvement technology, (b) land care and post harvest, (c) application of PLTB, (d) prevention of land fires, (e) socialization of ownership status, (f) related to agricultural cultivation, fisheries, animal husbandry, plantation and forestry

4. $\quad$ Ability to understand the material (very capable $=3$; capable $=2$; unable to $=1$ ) 
5. Number of technologies applied (high $(>3$ technology) $=3$; medium $(1-3$ technologies $)=2$; low $(<1$ technology $)=1)$

Determination of the number of technology applications based on tendency central from the overall respondents' answers. Technology consists of (a) technology in land preparation, (b) technology in planting/irrigation/nursery, (c) technology in fertilization/spraying, (d) technology in weeding, (e) technology in harvesting

$x_{2}=$ Land ownership status $($ Score: property $=3$, rent $/$ ride $=2$, labor $=1$ )

$x_{3}=$ Land productivity $(\mathrm{Rp} . / \mathrm{Ha})$

Total household income divided by the area of land cultivated

$x_{4}=$ Percentage of farm income (\%)

Total farm income divided by total household income

$x_{5}=$ Organizational activism (total score)

Shows the respondent's participation in village organizations. The total score is the total score of the indicators:

1. Membership status (active as administrator $=3$; active as a member $=$ 2 ; inactive $=1$ )

2. Frequency of participation in organizational activities (high frequency $(>15$ times $)=3$; medium frequency $(10-15$ times $)=2$; low frequency $(<10$ times $)=1$

The determination of frequency is based on tendency central from the overall respondents' answers

$x_{6}=$ Cooperation activity (total score)

The total score is the total score of the indicators:

1. Activity level (active $=2$; inactive $=1$ )

2. Frequency of participating in mutual cooperation activities (high frequency $(>35$ times $)=3$; medium frequency $(5-35$ times $)=2$; low frequency $(<5$ times $)=1)$

The determination of frequency is based on tendency central from the overall respondents' answers

$x_{7}=$ Imitation rate (total score)

Explain the respondent's ability to imitate other people's habits in using fire The total score is the number of answers from the indicators:

1. The assumption that there are still many local residents who use fire on the land

2. The decision to use fire on the land is influenced by other people

$x_{8}=$ Land location $(\mathrm{m})$

Land distance from residence

$x_{9}=$ Cosmopolitan (total score)

Describes the attitude of openness of respondents to influences outside the village

The total score is the total score of the indicators:

1. Has connections outside the village $($ many $=3 ;$ medium $=2$; none $=1$ )

2. Frequency of leaving the village (high frequency $(>3$ times) $=3$; medium frequency $(2-3$ times $)=2$; low frequency $(<2$ times $)=1)$

The determination of frequency is based on tendency central from the overall respondents' answers

$x_{10}=$ Outpouring of working time (HOK)

The number of working days on the farm in one year

$x_{11}=\quad$ Free time on the ground (hours)

The length of free time spent on farms

$x_{12}=$ Duration of land preparation (days)

The duration of land preparation until planting time

$x_{13}=$ Type of vegetation/land cover

Describes the volume/density of vegetation covering land prior to land preparation (bawas (used land) $=3$; bush $=2$; open land $=1$ )

$x_{14}=$ Livelihood patterns (hours) 


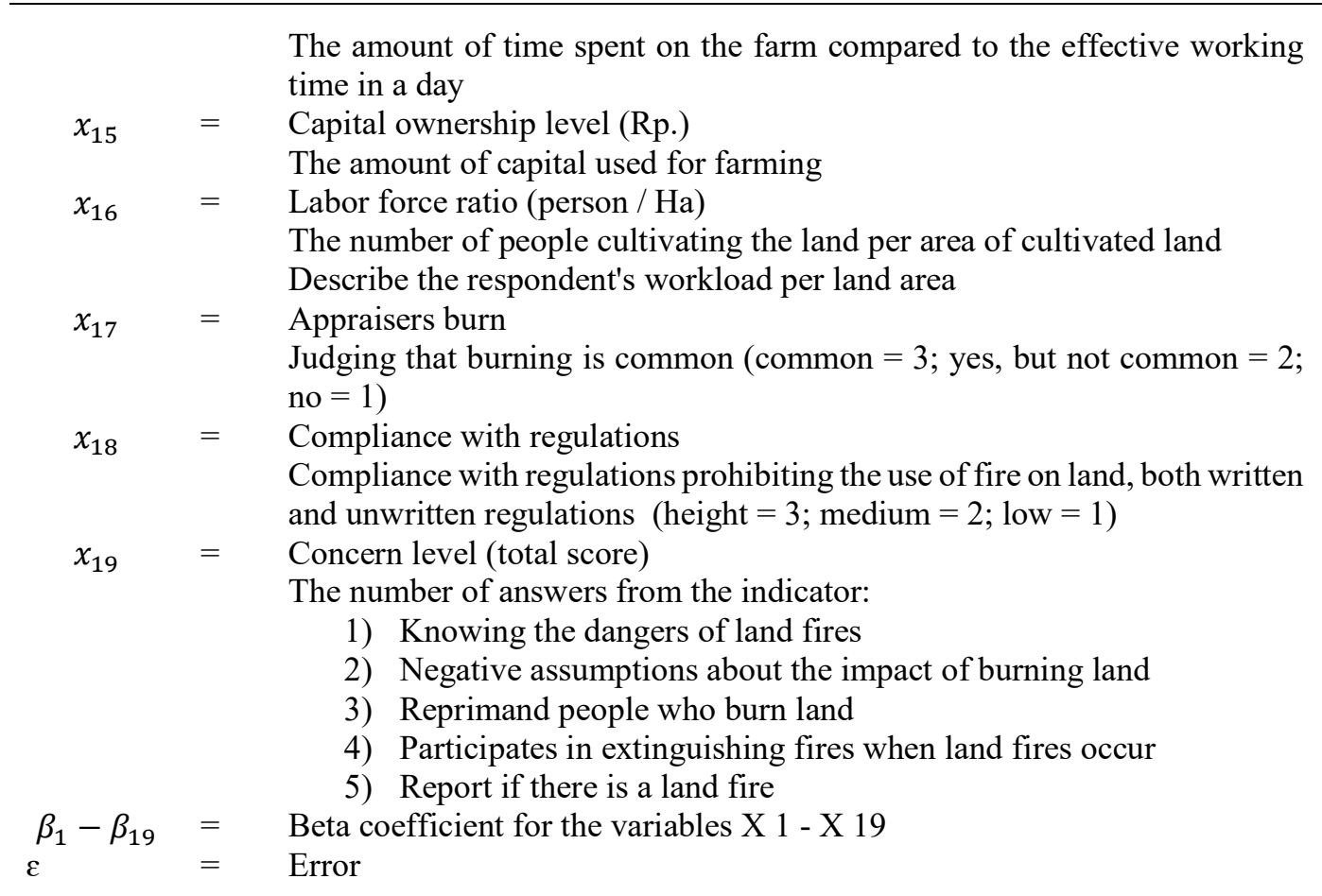

\section{Results and Discussion}

\subsection{Analysis of Burning Behavior in West Kalimantan Province}

Analysis of the behavior of burning land in West Kalimantan Province was carried out by combining survey data in Bengkayang and Kubu Raya Districts. The results of the analysis show that there are several variables that significantly influence the burning behavior. The result is explained in the Table 1.

The results of the analysis show that there are several factors that influence the behavior of burning land significantly. The Variables affecting land burning behavior is explained in the Table 2. Based on the analysis, it is known that land ownership factors influence the behavior of using fire on land significantly, where land owners tend not to use fire on the land, while land users with status as tenants or agricultural laborers tend to have a greater chance of using fire on the land. Another factor that has a significant influence is the level of imitation, where the higher the level of imitation of farmers against other farmers in the vicinity, the greater the chance of burning the land. This is because they think burning is a common thing done by other people in their environment. Cosmopolitan level has a significant influence and negative correlation. Farmers with high cosmopolitan levels tend not to use fire on the land. Meanwhile, the factor of working time on the land shows that the higher working time on the land causes farmers to tend to use fire. Another significant factor is the type of vegetation in the land before planting. Land covered with bawas tends to have a greater chance of burning when it is planted. The last factor that significantly influences the behavior of burning land is the assessment of burning activity. Farmers who think that burning land is common tends to use fire on their land. 
Table 1. Results of Analysis of Land Burning Behavior in West Kalimantan Province

\begin{tabular}{|c|c|c|c|c|c|c|c|}
\hline \multirow[t]{2}{*}{ Variable } & \multicolumn{3}{|c|}{$\begin{array}{c}Y_{1} \\
\text { (Burning Behavior) }\end{array}$} & \multicolumn{2}{|c|}{$\begin{array}{c}Y_{2} \\
\text { (Burn Frequency) }\end{array}$} & \multicolumn{2}{|c|}{$\begin{array}{c}Y_{3} \\
\text { (Burn area) }\end{array}$} \\
\hline & Coef. & Sig. & $\operatorname{Exp}(B)$ & Coef. & Sig. & Coef. & Sig. \\
\hline Diffusion rate of innovation $\left(x_{1}\right)$ & -.050 & .108 & .951 & -.015 & .747 & -.043 & .340 \\
\hline Land ownership status $\left(x_{2}\right)$ & -358 & $.000^{*}$ & .699 & -.039 & .427 & .145 & $.002 *$ \\
\hline Land productivity $\left(x_{3}\right)$ & .000 & .516 & 1,000 & .146 & .052 & -.051 & .473 \\
\hline Percentage of income $\left(x_{4}\right)$ & .002 & .282 & 1,002 & & & & \\
\hline Organizational activism $\left(x_{5}\right)$ & -114 & .382 & .892 & & & & \\
\hline Cooperation activity $\left(x_{6}\right)$ & -.020 & .823 & .980 & -119 & $.012^{*}$ & .050 & .261 \\
\hline Imitation level $\left(x_{7}\right)$ & .292 & $.000^{*}$ & 1,339 & .079 & .144 & .166 & $.001^{*}$ \\
\hline Land location $\left(x_{8}\right)$ & .003 & .108 & 1,003 & -.011 & .816 & -.017 & .689 \\
\hline Cosmopolitan $\left(x_{9}\right)$ & -.300 & $.000^{*}$ & .741 & & & & \\
\hline Outline of working time $\left(x_{10}\right)$ & .003 & $.017^{*}$ & 1,003 & .057 & .243 & .029 & .523 \\
\hline Free time on the ground $\left(x_{11}\right)$ & .097 & .249 & 1,102 & -.099 & $.039^{*}$ & .015 & .740 \\
\hline Duration of tillage $\left(x_{12}\right)$ & -.010 & .140 & .990 & .001 & .991 & -.091 & $.043^{*}$ \\
\hline Type of vegetation/land cover $\left(x_{13}\right)$ & .015 & $.003^{*}$ & 1,015 & .024 & .616 & .078 & .083 \\
\hline Livelihood patterns $\left(x_{14}\right)$ & .356 & .367 & 1,427 & .031 & .526 & .030 & .516 \\
\hline Capital Ownership $\left(x_{15}\right)$ & .000 & .152 & 1,000 & -.047 & .304 & -.074 & .088 \\
\hline Labor ratio $\left(x_{16}\right)$ & 23,731 & .691 & $2.024 \mathrm{E} 10$ & -.065 & .379 & -.027 & .703 \\
\hline Burn rating $\left(x_{17}\right)$ & .507 & $.000^{*}$ & 1,661 & .026 & .631 & .143 & $.005^{*}$ \\
\hline Compliance with regulations $\left(x_{18}\right)$ & -.062 & .476 & .940 & -.029 & .533 & -173 & $.000^{*}$ \\
\hline Concern level $\left(x_{19}\right)$ & -.021 & .840 & .980 & -008 & .874 & -.087 & .054 \\
\hline Constant & .408 & .661 & 1,503 & & .797 & & .003 \\
\hline $\mathbf{R}^{2}$ & \multicolumn{3}{|c|}{.416} & \multicolumn{2}{|c|}{.314} & \multicolumn{2}{|c|}{.323} \\
\hline $\mathrm{N}$ & \multicolumn{3}{|c|}{1560} & \multicolumn{2}{|c|}{482} & \multicolumn{2}{|c|}{482} \\
\hline
\end{tabular}

Source: Results of primary data analysis (2015)

Note: $*$ Significant at the $95 \%$ confidence level

The behavior of burning land as seen from the frequency and area of land that is burned is also influenced by several factors, namely the activity of mutual cooperation and free time on the land which affects the frequency of burning the land. Meanwhile, the area of land that is burned is influenced by land ownership status, level of imitation, duration of land preparation, burning assessment and legal compliance.

Behaviors community to burn land influenced by two sub factors, it is direct sub factor and indirect. Sub-factor directly engages productive land, transmigration, developer of an irrigation, expansion of agriculture, land management, fuel/dry ingredients are flammable, sparks coming from other areas, clearing land agriculture with methods of burning, the drying up marshes, the practice of illegal logging are still many discovered, factors lack accidental from the activity of human (cigarette butts). Sub- factor does not directly include land ownership, land conflicts, the policy of government in concession forests, the use of fire for household activities [1]-[7]. 
Table 2. Variables Affecting Land Burning Behavior Significantly in West Kalimantan Province

\begin{tabular}{|c|c|c|c|}
\hline $\begin{array}{l}\text { Independent } \\
\text { Variable }\end{array}$ & $Y_{1}$ & $Y_{2}$ & $Y_{3}$ \\
\hline $\begin{array}{l}\text { Land } \\
\text { ownership } \\
\text { status }\end{array}$ & $\begin{array}{l}\text { Land owners tend not to } \\
\text { burn land }\end{array}$ & & $\begin{array}{l}\text { Land owners who are still } \\
\text { burning tend to burn large } \\
\text { areas of land }\end{array}$ \\
\hline Mutual activity & & $\begin{array}{l}\text { Respondents who were } \\
\text { more active in gotong } \\
\text { royong activities } \\
\text { tended to burn less } \\
\text { frequently }\end{array}$ & \\
\hline Imitation level & $\begin{array}{l}\text { Respondents with a high } \\
\text { level of imitation } \\
\text { behavior tend to burn } \\
\text { land }\end{array}$ & & $\begin{array}{l}\text { Respondents with a high } \\
\text { level of imitation } \\
\text { behavior tend to burn } \\
\text { large areas of land }\end{array}$ \\
\hline Cosmopolitan & $\begin{array}{l}\text { Respondents with high } \\
\text { cosmopolitan levels } \\
\text { tend not to burn land }\end{array}$ & & \\
\hline $\begin{array}{l}\text { Spilled work } \\
\text { time }\end{array}$ & $\begin{array}{l}\text { Respondents with a high } \\
\text { amount of time spent } \\
\text { working on agricultural } \\
\text { land tended to burn the } \\
\text { land }\end{array}$ & & \\
\hline $\begin{array}{l}\text { Free time on } \\
\text { the ground }\end{array}$ & & $\begin{array}{l}\text { Respondents who have } \\
\text { more free time on the } \\
\text { ground, the frequency } \\
\text { of burning tends to be } \\
\text { low }\end{array}$ & \\
\hline $\begin{array}{l}\text { Duration of } \\
\text { tillage }\end{array}$ & & & $\begin{array}{l}\text { Respondents with a } \\
\text { shorter duration of land } \\
\text { preparation tended to } \\
\text { burn with a larger area }\end{array}$ \\
\hline $\begin{array}{l}\text { Type of } \\
\text { vegetation/land } \\
\text { cover }\end{array}$ & $\begin{array}{l}\text { Respondents cultivating } \\
\text { land with bawas cover } \\
\text { tended to burn the land }\end{array}$ & & \\
\hline $\begin{array}{l}\text { Assessment } \\
\text { burn }\end{array}$ & $\begin{array}{l}\text { Respondents who } \\
\text { considered burning land } \\
\text { a natural thing tended to } \\
\text { burn the land }\end{array}$ & & $\begin{array}{l}\text { Respondents who } \\
\text { considered burning land a } \\
\text { natural thing tended to } \\
\text { burn large areas of land }\end{array}$ \\
\hline $\begin{array}{l}\text { Compliance } \\
\text { with } \\
\text { regulations }\end{array}$ & & & $\begin{array}{l}\text { Respondents with low } \\
\text { compliance tended to } \\
\text { burn large areas of land }\end{array}$ \\
\hline
\end{tabular}

Source: Primary data analysis (2016)

Forest and land fires happening a lot on the land area of the use of other (APL), due to the activity of the people on the land over many in the business estates and interests of others [8]. Cleaning the land by way of burning requires a time that is relatively more quickly and issuing costs are more inexpensive compared with mencangku 1 and nurture.

The reason that generally underlies burning is because the community is more interested in using wood for subsistence and turning the forest into shifting cultivation [9]. Other causes of fire there 
was timber logging and conversion of forests secunder into plantations [10]. In the research [11] said that the source of peatland fires also came from farmers and fishermen.

\subsection{The Burning Behavior Change Model}

The effort to prevent land fires is the formulation of a fire prevention model through an approach to changing people's behavior in using fire on the land. The model is formulated based on the results of the analysis of the factors that influence the behavior of burning land, based on the results of field observations in the period 2011-2016, and based on a study of supporting theories. The results of observations and theories that underlie the formulation of the model can be seen in Table 3.

Table 3. Theories Supporting the Underlying Change Behavior

\begin{tabular}{|c|c|c|}
\hline No. & Researcher & Supporting Theory \\
\hline 1. & $\begin{array}{l}\text { UNTAN Social } \\
\text { and Social Survey } \\
\text { Team }(2016)\end{array}$ & $\begin{array}{l}\text { Changes in fire use behavior occur due to stimuli in the form of } \\
\text { diffusion of innovation (imitation and cosmopolitan), agreement and } \\
\text { positive pressures in a community group. }\end{array}$ \\
\hline 2. & Soekanto (1985) & $\begin{array}{l}\text { Imitation is the act or attempt to imitate the actions of another person } \\
\text { as the ideal character. Imitation tends to be done by someone } \\
\text { unconsciously. } \\
\text { Farmers tend not to have knowledge related to agricultural } \\
\text { management without burning, so they imitate land burning that occurs } \\
\text { in their social system. }\end{array}$ \\
\hline 3. & $\begin{array}{l}\text { Siregar et } \\
\text { al (2015) }\end{array}$ & $\begin{array}{l}\text { Regarding the cosmopolitan level of forest communities, it proves that } \\
\text { a high level of cosmopolitanism is associated with high knowledge } \\
\text { regarding forest management. This means that farmers who interact } \\
\text { more with the environment outside the village are less likely to burn } \\
\text { land and are more open to innovation. }\end{array}$ \\
\hline 4. & $\begin{array}{l}\text { Roger and } \\
\text { Shoemaker (1995) }\end{array}$ & $\begin{array}{l}\text { Cosmopolitans affects positive perceptions of forestry } \\
\text { management. This cosmopolitanism is measured by looking at the } \\
\text { level of openness of rural communities to outsiders and information in } \\
\text { the form of innovation. Regarding the adoption of innovation, the } \\
\text { more cosmopolitics farmers are, the easier it is to accept outside } \\
\text { innovations. }\end{array}$ \\
\hline
\end{tabular}

The land and forest fire prevention model which is formulated based on the results of an analysis of the behavior of fire use in the land, as well as the supporting theory mathematically can be written in the following linear model:

$$
Y=\alpha+\beta_{1} x_{1}+\beta_{2} x_{2}+\beta_{3} x_{3}+\varepsilon
$$

where $\mathrm{Y}=$ Change in behavior; $x_{1}=$ Assistance activity; $x_{2}=$ Agreement/positive pressure (community judgment); $x_{3}=$ Stimulus of social capital (diffusion of innovation, cosmopolitan, mutual cooperation, compliance with regulations, and imitation). 
Model that indicates that changes in behavior will be influenced by the activity of assistance, stimulus social capital and agreements/pressure positive (assessment community). The model can be described in the following schematic:

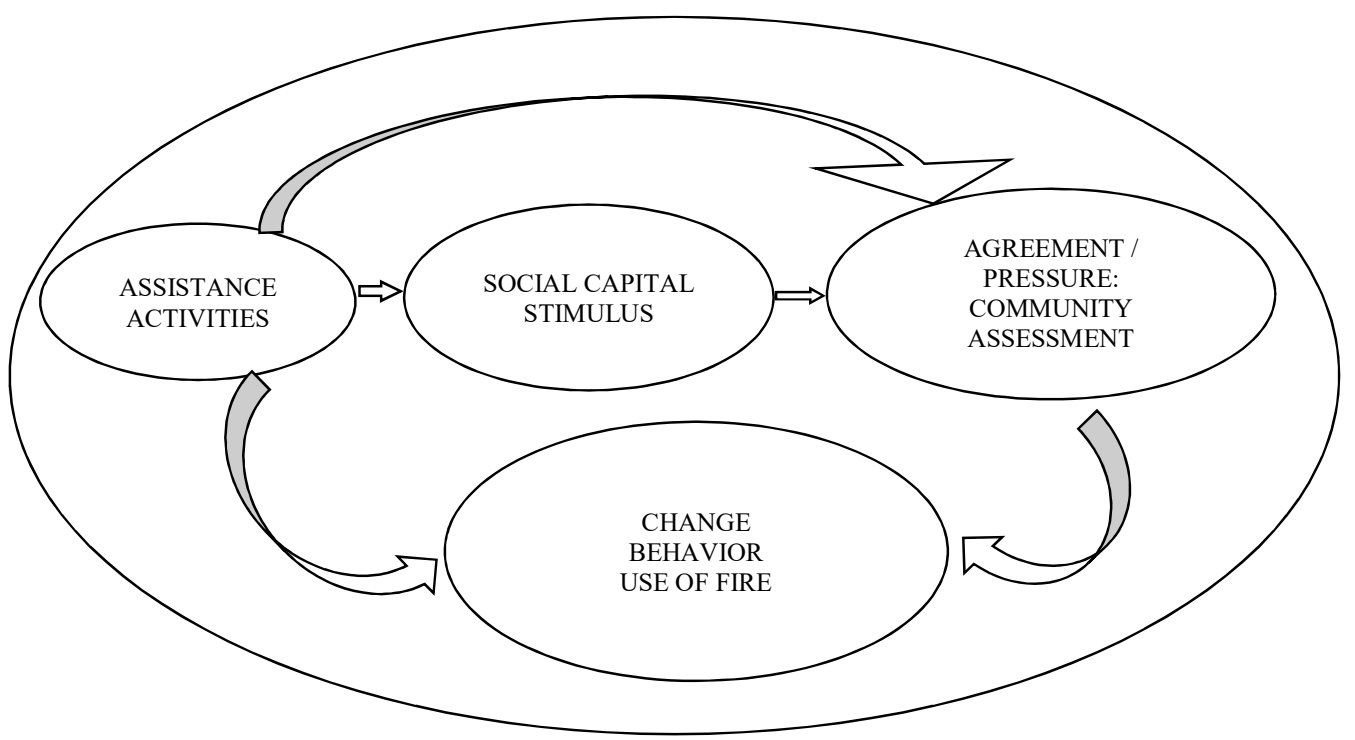

Figure 1. The Fire Use Behavior Change Model

These behavioral changes can be made by the three elements of the main interrelated one with the other that mentoring activity, stimulus social capital (the diffusion of innovation, cosmopolitan, mutual cooperation, adherence to regulations, and imitation) and agreements / pressure that is positive. If one element is not active or do not play a role, then the change in behavior will not be realized.

Assistance activities are needed as a control for the community in trying to prevent land and forest fires, with an approach as a facilitator in community activities aimed at prevention. These assistance activities can also play a role in efforts to provide positive pressure on the community through the approach of community assessment of behavior using fire on land. This is related to several significant factors from the results of the analysis, including mutual cooperation activities that can reduce the frequency of burning land, as well as enforcement of regulations by farmers which tends to reduce the area of land burned by these farmers. Then furthermore, assistance activities can also be an approach in providing a social capital stimulus for the community.

Efforts to prevent land and forest fires in peatland areas require socialization support, budget, human resources, equipment, and collaboration between local governments, extension agencies, the Ministry of Forestry through Mangala Agni, farmer groups and village government officials [2], [4]. The strategies for preventing forest and land fires according to [8] are: 1) Increasing the role of $U$ U and central government support; 2) Optimizing the involvement of regional heads, NGOs, communities and universities; 3 ) Strengthening the function of spatial use arrangement in 
RT/RW documents to overcome various spatial problems; 4) Increasing the role of the legislature in supervision, legislation and budgeting; 5) Law enforcement violations of statutory provisions; 6) Improve coordination between institutions and clarify the main tasks and functions of SKPD and improve the quality of human resources to cope with population growth rates and overcome spatial problems.

Forest and land fire prevention activities can be carried out through the creation of a Fire Service Unit (Satgasdamkar), making yellow firebreaks around fire-prone areas, counseling forest fires in each fire-prone village, as well as measuring the area and making a map of critical land [12]. Forest and land fire prevention activities that have been carried out in priority provinces are canal blocking, socialization to the public, education and counseling, publications / opinions through mass media, law enforcement investigations and law enforcement, technological innovation [13].

Balance of power and struggle among stakeholders (including the community) [14]. Harmonization among various policy sectors and interests [15]. Sustainable forest management [16]. The ability of local policies and local projects to consider climate adaptation [17]. Technical and political challenges to clarifying tenure [18]. Recognition of rights for forest communities [19]. All of these factors influence the success or failure of forest and land fire prevention efforts at the community level.

\section{Conclusion}

Land burning behavior that exist in the community in the push by several factors such as the status of ownership of land, the level of imitation, cosmopolitan, outpouring time work, type of vegetation/cover land and ratings burn. Then coupled with a lack of knowledge of the public about the result which caused $\mathrm{d}$ ari burn land so that the public is more pleased to burn land because considered more quickly and cost saving. To be able to prevent the occurrence of wag land it needs to be in the employ three things important that the activity of assistance, stimulus social capital and agreements/pressure that is positive. With this community better understand the dangers of burning the land and be able to change the pattern of habits of society which the at love to burn the land became lost and move on to the way that a more hospitable environment.

\section{REFERENCES}

[1] I. Zulkifli and L. Kamarubayana, "Studi Pengendalian Kebakaran Hutan di Wilayah Kelurahan Merdeka Kecamatan Samboja Kalimantan Timur," AGRIFOR, vol. 16, no. 1, pp. 141-150, 2017.

[2] S. A. Cahyono, S. P. Warsito, W. Andayani, and D. H. Darwanto, "Faktor-faktor yang mempengaruhi kebakaran hutan di indonesia dan implikasi kebijakannya," J. Sylva Lestari, vol. 3, no. 1, pp. 103-112, 2015.

[3] A. Loren, M. Ruslan, F. H. Yusran, and F. Rianawati, "Analisis Faktor Penyebab Kebakaran Hutan dan Lahan Serta Upaya Pencegahan yang Dilakukan Masyarakat di Kecamatan 
Basarang Kabupaten Kapuas Kalimantan Tengah,” EnviroScienteae, vol. 11, no. 1, pp. 1-9, 2016.

[4] B. Nasrul, "Program of community empowerment prevents forest fires in Indonesian peat land," Procedia Environ. Sci., vol. 17, pp. 129-134, 2013.

[5] M. I. Ishihara, R. Firdaus, and N. Nakagoshi, "Peatland Fires in Riau, Indonesia, in Relation to Land Cover Type, Land Management, Landholder, and Spatial Management," J. Environ. Prot. (Irvine,. Calif)., vol. 8, no. 11, p. 1312, 2017.

[6] D. L. A. Gaveau et al., "Major atmospheric emissions from peat fires in Southeast Asia during non-drought years: evidence from the 2013 Sumatran fires," Sci. Rep., vol. 4, p. 6112, 2014.

[7] M. E. Marlier et al., "Fire emissions and regional air quality impacts from fires in oil palm, timber, and logging concessions in Indonesia," Environ. Res. Lett., vol. 10, no. 8, p. 85005, 2015.

[8] S. Supriyanto, S. Syarifudin, and A. Ardi, "Analisis Kebijakan Pencegahan Dan Pengendalian Kebakaran Hutan Dan Lahan Di Provinsi Jambi," J. Pembang. Berkelanjutan, vol. 1, no. 2, pp. 94-104, 2018.

[9] M. Z. Muttaqin, I. Alviya, M. Lugina, and F. A. U. Hamdani, "Developing community-based forest ecosystem service management to reduce emissions from deforestation and forest degradation," For. policy Econ., vol. 108, p. 101938, 2019.

[10] A. S. Thoha, B. H. Saharjo, R. Boer, and M. Ardiansyah, "Characteristics and causes of forest and land fires in Kapuas District, Central Kalimantan Province, Indonesia," Biodiversitas J. Biol. Divers., vol. 20, no. 1, pp. 110-117, 2019.

[11] A. A. Acep Akbar, S. Sumardi, I. R. H. Purwanto, I. R. H. Purwanto, and S. S. Sambas Sabarnudin, "Studi sumber penyebab terjadinya kebakaran lahan dan respon masyarakat dalam rangka pengendalian kebakaran hutan gambut di areal Mawas Kalimantan Tengah.," J. Penelit. hutan Tanam., vol. 8, no. 5, pp. 287-300, 2011.

[12] J. Irwandi and B. Ismail, "Upaya Penanggulangan Kebakaran Hutan Dan Lahan Di Desa Purwajaya Kecamatan Loa Janan Kabupaten Kutai Kertanegara Kalimantan Timur," Agrifor, vol. 15, no. 2, pp. 201-210, 2016.

[13] K. A. Wibowo, "Manajemen Penanganan Kebakaran Hutan dan Lahan (Karhutla) Guna Peningkatan Ekonomi Kerakyatan,” J. Stud. Sos. dan Polit., vol. 3, no. 1, pp. 69-83, 2019.

[14] A. A. Makatta, F. P. Maganga, and A. E. Majule, "A hidden pitfall for REDD: analysis of power relation in participatory forest management on whether it is an obstacle or a reliever on REDD pathway," Int. J. For. Res., vol. 2015, 2015.

[15] T. Fujisaki, K. Hyakumura, H. Scheyvens, and T. Cadman, "Does REDD+ ensure sectoral coordination and stakeholder participation? A comparative analysis of REDD+ national governance structures in countries of Asia-Pacific region," Forests, vol. 7, no. 9, p. 195, 2016.

[16] S. Shrestha, B. S. Karky, and S. Karki, "Case study report: REDD+ pilot project in community forests in three watersheds of Nepal," Forests, vol. 5, no. 10, pp. 2425-2439, 2014.

[17] P. McElwee et al., "Using REDD+ policy to facilitate climate adaptation at the local level: synergies and challenges in Vietnam," Forests, vol. 8, no. 1, p. 11, 2017.

[18] L. Loft et al., "Taking stock of carbon rights in REDD+ candidate countries: concept meets reality," Forests, vol. 6, no. 4, pp. 1031-1060, 2015.

[19] J. Pelletier, N. Gélinas, and M. Skutsch, "The place of community forest management in the REDD+ landscape," Forests, vol. 7, no. 8, p. 170, 2016. 